Tyndale Bulletin 67.2 (2016) 309-312

\title{
DEATH AND DIVINE JUDGEMENT IN ECCLESIASTES ${ }^{1}$
}

\author{
Kumiko Takeuchi \\ (jktakeuchi@gmail.com)
}

Ecclesiastes among the OT books is an anomaly, but not without its significance. After all, it has survived inquiries about its questionable content and remains a part of canonical Scripture. The unusual content of Ecclesiastes may be related to certain historical circumstances when it was written. As there is little internal or external evidence, however, it is no easy task to assign the book's date to any particular period. Premised on the current consensus regarding its plausible dating between the 6th and 3rd centuries, albeit mainly based on linguistic evidence, one may well ask: what is the book of Ecclesiastes doing, if it appeared on the cusp of the Persian-Hellenistic transition period, when the traditional idea of theodicy was perhaps becoming a serious issue in Israelite society before full-blown apocalyptic eschatology surfaced? This thesis probes that question.

In Ecclesiastes Qohelet speaks about many different things which happen in life, but he eventually sums everything up by saying, 'Everything is hebel'. Death apparently is the reason. How can everything (הכל) that one accomplishes be assessed as 'futile' (הבל) apropos of death? Why is Qohelet so obsessed with death? Why does Ecclesiastes connote a more negative and sceptical tone than perhaps warranted as wisdom literature? What might the author have intended to convey to his reader? Qohelet assesses every event in life in terms of death, which occasions injustice. Answers to the puzzles of Ecclesiastes seem to be inseparable from questions of how best Ecclesiastes is to be read. This thesis contends that the book of Ecclesiastes is actually making a case for posthumous divine judgement as theological necessity. Further, judging from its implied

${ }^{1}$ Kumiko Takeuchi, 'Death and Divine Judgement in Ecclesiastes' (PhD dissertation, University of Durham, 2015); supervisors: Professors R. W. L. Moberly and Stuart Weeks. 
social and historical context, the book may have served perhaps as a provocative voice for, or a catalyst to, the emergence of apocalyptic eschatology and later sectarian conflicts within Judaism during the mid-Second Temple period.

For unravelling these issues, the problems associated with reading Ecclesiastes are identified in the Introduction. One problem is related to the book itself and the other to the historical social background, neither of which is straightforward to clarify. In developing the current thesis, three main objectives were set forth: first, identify issues of death and divine judgement in Qohelet's monologue within the broader ancient Near Eastern context; second, devise or modify current approaches for how best Ecclesiastes is to be read as a unity and attempt to resolve incoherences in the book; and third, argue for the case proposed in this thesis.

Chapter 1 starts with a survey of the wider ancient Near Eastern setting to contextualise the specific discussion on the issues of death, injustice, and divine judgment in Ecclesiastes. The initial task for this purpose was to investigate the concept of death, afterlife, and divine judgement in the ancient world. What is most strikingly common in these concepts is that ancient people seem to have conceived of and believed in some form of post-mortem existence. They sought survival of their 'soul' or 'spirit' in various ways, supposing that their continuing being would reside in the netherworld. Egyptians believed in a divine judgement after death, but people in other nations of the ancient Near East did not hold the same view.

Funerary cults of the dead developed along with an afterlife concept and lasted with little change. Doubt and scepticism about the afterlife were raised and exacerbated when people found their tradition became unsatisfactory or questionable. Such a shift was more notably manifested in Egypt and Israel when extensive changes in their society began to threaten their national and individual security under foreign powers during the Persian and Hellenistic periods. Egyptian demotic literature and Ecclesiastes express similar sentiments concerning inscrutable divine activities and scepticism regarding human fate and the afterlife in the netherworld.

In Chapter 2 the two distinct recent approaches, canonical and frame-narrative readings, are examined and argued for how best Ecclesiastes may be read as a unified whole. Reading the book as an authorial frame-narrative rather than as an editorial work within a 
canonical approach is found preferable in this thesis. The framenarrator's presence and participation in the entire discourse is explicated by closely analysing the third-person voice which appears at the three key junctions, particularly his interruption in 7:27 in the middle of Qohelet's speech. This thesis identifies the frame-narrator as the most reliable voice, playing the pivotal role in Ecclesiastes, in contrast to Fox's view. Qohelet's voice may not necessarily have to reflect the author's view, but the frame-narrator is likely the author's disguise.

This interpretation departs from conventional historical approaches and from Fox. Many scholars have endeavoured to explain what the author tries to communicate through Qohelet, whom they consider to be the protagonist. If Qohelet does not represent or express the author's view, why then does Qohelet's monologue appear so prominent in Ecclesiastes and how is it meant to be integrated in the overall scheme of the book? One of the important aspects of interpreting Ecclesiastes, which is often overlooked, is how the immediate audience may have reacted or received Qohelet's message when it was delivered. What if Qohelet's words actually reflected their observations and sentiment in their society?

Issues raised and problems arising in Qohelet's monologue are then expounded in Chapters 3-4. Death and divine judgement, or the lack thereof, have surfaced as the two serious issues that Qohelet repeatedly mentions, although he does not always use the words 'death' or 'injustice' directly. Instead, Qohelet distinctly uses such terms as 'chance occurrence' or מקום 'place' to point to death by characterising them as 'the same' (אחדה) for 'all' (הכלד): 'All have the same happenstance' and 'All go to the same place'. Qohelet brings up the subject of death and its effects in almost every chapter of Ecclesiastes. He describes everyone facing the same fate - death - as 'an evil among all that happens, or that is done, under the sun': to Qohelet, it is the greatest רע 'evil, bad' among all the events in human life (9:3a-b).

In a similar vein, Qohelet observes injustice being prevalent in his society, but not rectified because of death. Nonetheless, he repeatedly affirms that God will judge because there is a time for everything, despite the fact the righteous perish in their righteousness and the wicked prevail in their wicked deeds. Justice de facto is not done, or justice de jure delayed. Qohelet's contradiction is apparent, because the 
only resolution he presents to his audience is to enjoy life while they can. There is no human activity after death. He even exhorts them not to be too righteous or too wicked, for either extreme risks their lives. Qohelet has no answer to death rendering permanent the injustice experienced during this life.

Discussions for making sense of conflicts and inconsistencies within Qohelet's monologic discourse and its relationship to the epilogue follow in Chapter 5. Here this thesis finds the poetic passage in 12:1-7 being the mainstay to hold together Qohelet's monologue and the frame-narrator's epilogue. Throughout history the passage has mostly been interpreted as an allegory of old age, but this thesis argues that it has very little to do with an old age theme but is likely depicting a coming judgement with eschatological foreboding. The poem and the epilogue can then be tied together by a theme of impending divine judgement, which is yet to come. A fresh interpretation of Qohelet's poem in 12:1-7 is a key because it may be functioning as a pivotal juncture, bridging the seemingly insurmountable gap between Qohelet's monologue and the frame-narrator's epilogue.

Finally, this thesis proposes that Qohelet's voice overall may be meant to be provocative, soliciting and inciting the audience to respond in the wake of inner conflict among Jews who are caught between their traditional belief and the new reality under foreign rulers during the Persian-Hellenistic transition period.

An analysis of circumstantial evidence suggests that Qohelet and apocalyptists likely lived in a similar social climate where traditional retributive justice was no longer at work (Chapter 6). Qohelet wrestled in his struggle, in which he could neither remain a 'traditionalist' nor become an 'innovator' of new hope as apocalyptists did. Nonetheless, Qohelet's message may have served as a provocation to a direction for emergence of uniquely Jewish apocalyptic eschatology. 